\title{
FORMULATION AND EVALUATION OF CONTROLLED POROSITY OSMOTIC PUMP TABLETS FOR ZIDOVUDINE AND LAMIVUDINE COMBINATION USING FRUCTOSE AS OSMOGEN
}

\author{
Chinmaya Keshari Sahoo*1, Surepalli Ram Mohan Rao ${ }^{2}$, Muvvala Sudhakar ${ }^{3}$ \\ ${ }^{1}$ Ph.D Scholar, Department of Pharmaceutics, University College of Technology, Osmania University, Hyderabad,Telangana-500007, India \\ ${ }^{2}$ Professor, Mekelle Institute of Technology, Mekelle University, Mekelle, Ethiopia \\ ${ }^{3}$ Professor and Principal, Department of pharmaceutics, Malla Reddy College of Pharmacy, Maisammaguda, Secunderabad, Telangana- \\ 500014
}

\begin{abstract}
The present study deals with the development and evaluation of controlled porosity osmotic pump (CPOP) tablets of ZidovudineLamivudine. Wet granulation method was used for the development of core tablets. Core tablets were incorporated with HPMCE5 LV polymer, different concentrations of fructose as osmogen and additives. The CPOP tablets were coated with cellulose acetate as a wall forming material, polyethylene glycol as flux regulating agent, and sorbitol acts as pore forming material in SPM. The formulated tablets were evaluated for FTIR, DSC, pre-compression parameters, post compression parameters, in vitro drug release study and scanning electron microscopy study. The optimized formulation had no significant effect on the $\mathrm{p}^{\mathrm{H}}$ and agitation intensity, but depends on the osmotic pressure of dissolution media indicated that mechanism of drug release. SEM images revealed that no pores were found before dissolution and after dissolution had shown the porous nature of the membrane. Short term stability study at $40 \pm 2^{\circ} \mathrm{C} / 75 \pm 5 \% \mathrm{RH}$ for the months on the $\mathrm{CF} 4$ formulation indicated that there was no significant change weight variation, $\%$ friability, drug content and in vitro drug release.
\end{abstract}

Keywords: HPMCE5LV, wet granulation, CPOP, in vitro drug release, stability study.

Article Info: Received 14 May, 2017; Review Completed 30 June, 2017; Accepted 01 July, 2017; Available online 15 July, 2017

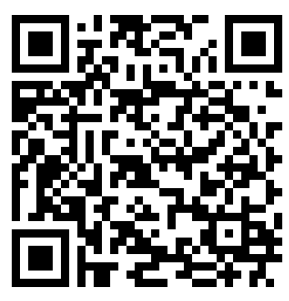

\section{Cite this article as:}

Sahoo CK, Rao SRM, Sudhakar M, Formulation and evaluation of controlled porosity osmotic pump tablets for Zidovudine and Lamivudine combination using fructose as osmogen, Journal of Drug Delivery and Therapeutics. 2017; 7(4):41-50

DOI: http://dx.doi.org/10.22270/jddt.v7i4.1465

*Address for Correspondence

Chinmaya Keshari Sahoo, Ph.D Scholar, Department of Pharmaceutics, University College of Technology, Osmania University, Hyderabad,Telangana-500007, India. Email: sahoo.chinmaya83@gmail.com

\section{INRODUCTION}

Controlled release dosage forms is the part of modified drug release dosage form which covers a wide range of prolonged ${ }^{1}$ action which provide continuous release of their active ingredients at predetermined rate and predetermined time. Out of various controlled drug delivery systems osmotic controlled drug delivery system (OCDDS) utilizes principle of osmotic pressure ${ }^{2}$ to control the delivery of active ingredients. The drug released from OCDDS is independent of $\mathrm{p}^{\mathrm{H}}$, hydrodynamic condition of the body and agitation intensity.
The present study is to develop controlled porosity osmotic pump tablets. CPOP tablets were developed where the delivery orifices were formed by the incorporation of a leachable component ${ }^{3}$ in SPM. The core is coated with cellulose acetate containing in situ micro pore former sorbitol. Once CPOP tablets come in contact with the aqueous environment of biological system the water soluble component dissolves and an osmotic pumping system is created in the core. Hence water diffuses into the core though the micro porous 4 membrane setting up an osmotic gradient and thereby controlling the release of drug. 
Globally AIDS is considered a dangerous disease which is caused by infection with human immune deficiency virus. The final stage of AIDS where the CD4+ count declines to 200 cells $/ \mu \mathrm{L}$. Out of various treatments now antiretroviral ${ }^{5}$ therapies plays a vital role for controlling the progression of AIDS. Combination therapy is used to be the advanced care of HIV infected patients. The current formulation containing $300 \mathrm{mg}$ Zidovudine and $150 \mathrm{mg}$ of Lamivudine has been formulated as an oral therapy (tablet) for the treatment of HIV-1 infection in adults. The development of this fixed dose combination ${ }^{6}$ aims to reduce the number of daily tablets, enhance the compliance therapy and thereby minimizing the risk of emergence of resistance.

\section{MATERIALS AND METHODS}

\section{Materials}

Zidovudine and Lamivudine were obtained from Hetero Drugs Pvt. Ltd. India. Fructose and mannitol were purchased from Qualigens Fine Chemicals, India. Cellulose acetate (CA) was obtained from Eastman Chemical Inc, Kingsport, TN. Sorbitol, HPMC E5 LV, magnesium stearate, talc and polyethylene glycol (PEG) 400, 600, 4000, 6000 were purchased from S.D. Fine Chemicals Ltd, Mumbai, India. Microcrystaline cellulose (MCC) and starch are purchased from Signet Pharma, Mumbai, India. All other solvents and reagents used were of analytical grade.

\section{Compatibility studies}

\section{Fourier Transform Infrared Spectroscopy (FTIR)}

In this method individual samples as well as the mixture ${ }^{7}$ of drug and excipients were ground mixed thoroughly with potassium bromide $(1: 100)$ for $3-5$ minutes in a mortar and compressed into disc by applying pressure of $10 \mathrm{~kg} / \mathrm{cm}$ to form a transparent pellet in hydraulic press. The pellet was kept in the sample holder and scanned from 4000 to $400 \mathrm{~cm}^{-1}$ in FTIR spectrophotometer (Bruker, Germany).

\section{Differential Scanning Calorimetry (DSC)}

Physical mixtures of drug and individual excipients in the ratio of $1: 1$ were taken and examined in DSC (Shimadzu DSC-50, Japan).Individual samples as well as physical mixture of drug and excipients ${ }^{8}$ were weighed to about $5 \mathrm{mg}$ in DSC pan. The sample pan was crimped for effective heat conduction and scanned in the temperature range of $50-300^{\circ} \mathrm{C}$. Heating rate of $20^{\circ} \mathrm{C}$ $\min ^{-1}$ was used and the thermogram obtained was reviewed for evidence of any interactions.

\section{Methods}

\section{Preparation of CPOP tablets}

Wet granulation technique was used to develop CPOP core tablets. Accurately weighed quantities of ingredients mentioned in Table 1 were sifted though sieve No. 30. Lubricant (magnesium stearate) and glidant (talc) were sifted though sieve No. 80.The ingredients were manually blended homogenously in a mortar by way of geometric dilution except lubricant and glidant. The mixture was moistened with aqueous solution and granulated though sieve No.30 and dried in a hot air oven at $60^{\circ} \mathrm{C}$ for sufficient time (3-4 hrs). The dried granules were passed though sieve No.30 and blended with talc and magnesium stearate. The homogenous blend was then compressed into round tablets with standard concave punches using 10 station rotary compression machines (Mini press, Karnavati, India).

Table1: Composition of controlled porosity osmotic pump tablets of zidovudine-lamivudine combination

\begin{tabular}{|l|l|l|l|l|}
\hline Ingredients (mg) & CF1 & CF2 & CF3 & CF4 \\
\hline ZD & 300 & 300 & 300 & 300 \\
\hline LD & 150 & 150 & 150 & 150 \\
\hline MCC & 150 & 120 & 90 & 60 \\
\hline Starch & 50 & 50 & 50 & 50 \\
\hline HPMC E5LV & 60 & 60 & 60 & 60 \\
\hline Fructose & 30 & 60 & 90 & 120 \\
\hline Magnesium stearate & 5 & 5 & 5 & 5 \\
\hline Talc & 5 & 5 & 5 & 5 \\
\hline Total weight(mg) & 750 & 750 & 750 & 750 \\
\hline
\end{tabular}

\section{Coating of core tablets}

The coating solution was prepared taking required ingredients from table 2 and acetone was added quantity sufficient maintaining proper viscosity of solution. The coatings of tablets were performed by spray pan coating in a perforated pan (GAC-205, Gansons Ltd, Mumbai,
India). Hot air is supplied to tablet bed by rotating lower speed 5-8 rpm initially. The coating of tablets was carried out with the rotation speed of 10-12 rpm. The spray rate and atomizing air pressure were $4-6 \mathrm{ml} / \mathrm{min}$ and $1.75 \mathrm{~kg} / \mathrm{cm}^{2}$ respectively. Inlet and outlet air temperature were $50^{\circ} \mathrm{C}$ and $40^{\circ} \mathrm{C}$ respectively. Coated tablets were dried at $50^{\circ} \mathrm{C}$ for $12 \mathrm{~h}$. 
Table 2: Coating composition for controlled porosity osmotic pump tablets

\begin{tabular}{|l|l|l|l|l|l|l|l|}
\hline Formulation code & $\begin{array}{l}\text { CA } \\
(\mathrm{g})\end{array}$ & $\begin{array}{l}\text { PEG 400 } \\
(\mathrm{g})\end{array}$ & $\begin{array}{l}\text { PEG 600 } \\
(\mathrm{g})\end{array}$ & $\begin{array}{l}\text { PEG 4000 } \\
(\mathrm{g})\end{array}$ & $\begin{array}{l}\text { PEG 6000 } \\
(\mathrm{g})\end{array}$ & $\begin{array}{l}\text { Sorbitol } \\
(\mathrm{g})\end{array}$ & $\begin{array}{l}\text { Acetone } \\
(\mathrm{mL})\end{array}$ \\
\hline CF1 & 6 & 2 & 0 & 0 & 0 & 0 & 300 \\
\hline CF2 & 6 & 0 & 2 & 0 & 0 & 0.6 & 300 \\
\hline CF3 & 6 & 0 & 0 & 2 & 0 & 1.2 & 300 \\
\hline CF4 & 6 & 0 & 0 & 0 & 2 & 1.8 & 300 \\
\hline
\end{tabular}

\section{Evaluation of granules}

The prepared granules were evaluated for pre compression parameters such as angle of repose, bulk density, tapped density and compressibility index (Carr's index). Fixed funnel method was used to determine angle of repose. The bulk density and tapped density were determined by bulk density apparatus (Sisco, India).

The Carr's index can be calculated by the following formula.

$\%$ Carr's index $=\frac{\text { et }-\mathrm{eb}}{\text { et }} \times 100$

Where $e_{t}$ is the tapped density of granules and $e_{b}$ is bulk density of granules.

Hausner's ratio can be calculated by the taking the ratio of tapped density to the ratio of bulk density ${ }^{9}$.

\section{Evaluation of tablets ${ }^{10}$}

\section{Thickness}

The thickness of individual tablets is measured by using vernier caliper (Absolute digimatic, Mitutoyo Corp. Japan).The limit of the thickness deviation of each tablet is $\pm 5 \%$.

\section{Measurement of coat thickness}

Film was isolated from the tablets after $18 \mathrm{hs}$ of dissolution and dried at $40^{\circ} \mathrm{C}$ for $1 \mathrm{~h}$. Thickness was measured by using electronic digital calipers (Absolute digimatic, Mitutoyo Corp. Japan)

\section{Hardness}

The hardness of tablets can be determined by using Monsanto hardness tester (Sisco, India).

\section{Friability test}

Friability test of tablets was performed in a Roche friabilator (SISCO, India).Twenty tablets of known weight $\left(\mathrm{W}_{1}\right)$ were de-dusted in plastic chamber of friabilator for a fixed time of $25 \mathrm{rpm}$ for 4 minutes and weighed again of weight $\left(\mathrm{W}_{2}\right)$.The percentage of friability was calculated using the following equation.

$\%$ Friability $=\mathrm{F}=\left(1-\frac{\mathrm{W} 2}{\mathrm{~W} 1}\right) \times 100$

Where, $\mathrm{W}_{1}$ and $\mathrm{W}_{2}$ are the weight of the tablets before and after the test respectively.

\section{Weight variation test}

The weight variation test is performed by weighing 20 tablets individually calculating the average weight and comparing the individual tablet weights to the average.
The percentage weight deviation was calculated and then compared with USP specifications.

\section{Uniformity of drug content test}

Powder is made after triturating 10 CPOP tablets from each batch with mortar and pestle. The powder weight equivalent to one tablet was dissolved in a $100 \mathrm{ml}$ volumetric flask filled with $0.1 \mathrm{~N} \mathrm{HCl}$ using magnetic stirrer for $24 \mathrm{~h}$. Solution was filtered though Whatman filter paper No.1 diluted suitably and analyzed spectro photometrically

\section{Diameter of tablet}

The diameter of individual tablets is measured by using vernier caliper (Absolute digimatic, Mitutoyo Corp. Japan).

\section{In vitro dissolution studies}

The in vitro dissolution ${ }^{11}$ studies were carried out using USP apparatus type II (Lab India 8000) at $75 \mathrm{rpm}$. For the first $2 \mathrm{~h}$ the dissolution medium was $0.1 \mathrm{~N} \mathrm{HCl}(\mathrm{pH}$ 1.2) and phosphate buffer $\mathrm{pH} 6.8$ from $3-8 \mathrm{~h}(900 \mathrm{ml})$, maintained at $37 \pm 0.5^{\circ} \mathrm{C}$. At each time point $5 \mathrm{ml}$ of sample was withdrawn and it was replaced with $5 \mathrm{ml}$ of fresh medium. The drug release at different time interval was measured by UV-visible spectrophotometer (UV1800, Shimadzu, Japan).

\section{In vitro drug release kinetic studies ${ }^{12,13}$}

In order to investigate the mode of release from tablets, the release data of formulation was analyzed zero order kinetics, first order kinetics, Higuchi model and Korsmeyer-Peppas and Hixson-Crowell equations.

\section{Effect of osmogen concentration}

Keeping all the parameters for tablet constant different osmogen ${ }^{14}$ concentrations were used to prepare tablets. The drug release was compared with the different osmogen concentration of formulated batches by using USP-II dissolution apparatus.

\section{Effect of pore former concentration}

SPM for various batches were prepared by taking different concentrations of pore former ${ }^{15}$. The effect of pore former on in vitro release profile is compared as well as number of formation of micropores were observed.

\section{Effect of membrane thickness}

Tablets with varying coating thicknesses were developed to demonstrate the effect of coating thickness on drug release. The drug release rate was measured using $0.1 \mathrm{~N}$ $\mathrm{HCl}$ and phosphate buffer $\mathrm{pH} 6.8$ as a dissolution medium. 


\section{Effect of flux regulating agents}

To assess the effect of flux regulating agents on drug release, formulations were developed with different flux regulating agents keeping all other parameters of tablet constant. The drug release was compared with the different flux regulating agents of formulated batches by using USP-II dissolution apparatus.

\section{Effect of osmotic pressure}

The effect of osmotic pressure ${ }^{16}$ was demonstrated by adding different amount of mannitol of an osmotic agent to produce $30 \mathrm{~atm}, 60 \mathrm{~atm}$ and $90 \mathrm{~atm}$ respectively in dissolution media $0.1 \mathrm{~N} \mathrm{HCl}$ for $2 \mathrm{~h}$ and phosphate buffer $\mathrm{pH} 6.8$ for remaining hours. The drug release rate was carried out in USP type II (Paddle) apparatus at $75 \mathrm{rpm}$ maintained at $37 \pm 0.5^{\circ} \mathrm{C}$ and compared for various dosage forms.

\section{Effect of pH}

The effect of $\mathrm{pH}^{17}$ for developed formulations were observed by performing the release studies of optimized formulation in different media $0.1 \mathrm{~N} \mathrm{HCl}(\mathrm{pH} \mathrm{1.2)}$, phosphate buffer $\mathrm{pH} 6.8$ and phosphate buffer in $\mathrm{pH} 7.4$ USP type II dissolution apparatus at $75 \mathrm{rpm}$. The temperature was maintained at $37 \pm 0.5^{\circ} \mathrm{C}$. The release was studied at predetermined time intervals.

\section{Effect of agitation intensity}

The effect of agitation ${ }^{18}$ intensity were observed by performing the release studies of optimized formulation in USP Type II (Paddle) dissolution apparatus containing $0.1 \mathrm{NHCl}$ for first $2 \mathrm{~h}$ and phosphate buffer pH 6.8 for remaining hours at different rotational speeds of 50,100 and $150 \mathrm{rpm}$ with maintaining temperature at $37 \pm 0.5^{\circ} \mathrm{C}$. The samples were withdrawn at predetermined intervals and analyzed by UV spectrophotometer.

\section{Scanning Electron Microscopy (SEM)}

Coating membranes of formulation were collected before and after complete dissolution of core contents and examined for their porous morphology ${ }^{19}$ as well as mechanism of drug release by scanning electron microscope (Leica, Bensheim, Switzerland). Scans were taken at an excitation voltage in SEM fitted with ion sputtering device.

\section{Accelerated stability studies}

The packed tablets in air tight container were placed in stability chambers (Thermo lab Scientific equipment Pvt. Ltd., Mumbai, India) maintained at $40 \pm 2^{0} \mathrm{C} / 75 \pm 5 \%$ RH conditions for accelerated testing) for 3 months ${ }^{20}$. Tablets were periodically removed and evaluated for physical characteristics, drug content, in-vitro drug release etc..

\section{RESULTS ANS DISCUSSION}

\section{FTIR studies:}

FTIR spectra (Figure 1) of Zidovudine shows the characteristic absorption peaks for the carbonyl group at $1638.76 \mathrm{~cm}^{-1}, \mathrm{~N}=\mathrm{N}^{+}=\mathrm{N}$ stretching (azido group) at $2114.50 \mathrm{~cm}^{-1}, \mathrm{C}-\mathrm{O}$ stretching at $1063.08 \mathrm{~cm}^{-1}$ and amine group stretching at $3317.86 \mathrm{~cm}^{-1}$. Figure 2 shows characteristic absorption peaks of Lamivudine for the C$\mathrm{H}$ stretching at $2843.83 \mathrm{~cm}^{-1}, \mathrm{~N}-\mathrm{H}$ bending at 1640.32 $\mathrm{cm}^{-1}, \mathrm{C}-\mathrm{N}$ stretching at $1010.71 \mathrm{~cm}^{-1}, \mathrm{O}-\mathrm{H}$ in plane bending at $1054.55 \mathrm{~cm}^{-1}$ and amine group stretching at $3326.6 \mathrm{~cm}^{-1}$.

The major peaks of HPMCE5LV were found at 3880.71, 3810.87 , 3713.83, 3669.20, 3601.84, 3566.74, 3557.95, $3473.68,3222.79,3117.03,3066.96,2982.59$, 2887.86, $2847.2, \quad 2803.12, \quad 2710.75, \quad 2618.99, \quad 2444.13$, 2335.14,2068.70, 1661.47, 1536.52, 1500.67, 1424.62, $1071.87,781.05$ and $584.97 \mathrm{~cm}^{-1}$. The major peaks of fructose were found at $3450.75,3120.47,3047.75$, 2722.80, 2464.30, 2310.70, 2102.48, 1914.04, 1502.21, 1391.71, 1102.14, 787.25, 677.36, and $599.13 \mathrm{~cm}^{-1}$.

In the optimized formulation CF4 peak at 3672.66, $1451.54,1251.27$ and $782.94 \mathrm{~cm}^{-1}$ were due to presence of the polymer HPMCE5LV.In the formulation the peaks present due to fructose were 2986.84, 1230.38 and $688.81 \mathrm{~cm}^{-1}$.Peaks at 3220.52 and $1065.68 \mathrm{~cm}^{-1}$ were due to presence of the drug Zidovudine in the optimized formulation and peaks at 1650.23 and $3326.98 \mathrm{~cm}^{-1}$ were due to presence of the drug Lamivudine. So from the study it can be concluded that the major peaks of drug $3220.52,1065.68,1650.23$ and $3326.98 \mathrm{~cm}^{-1}$ remain stable and no interaction was found between the drug, polymer and osmogen.

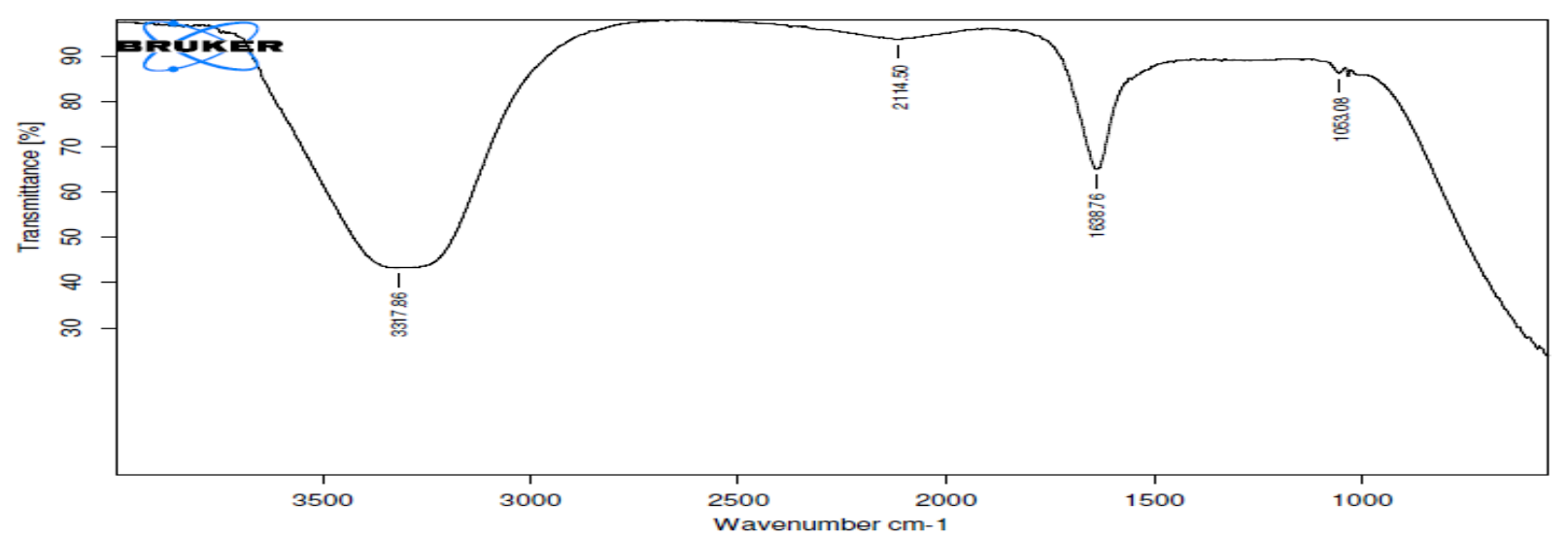

Figure 1: FTIR spectroscopy study of pure Zidovudine 


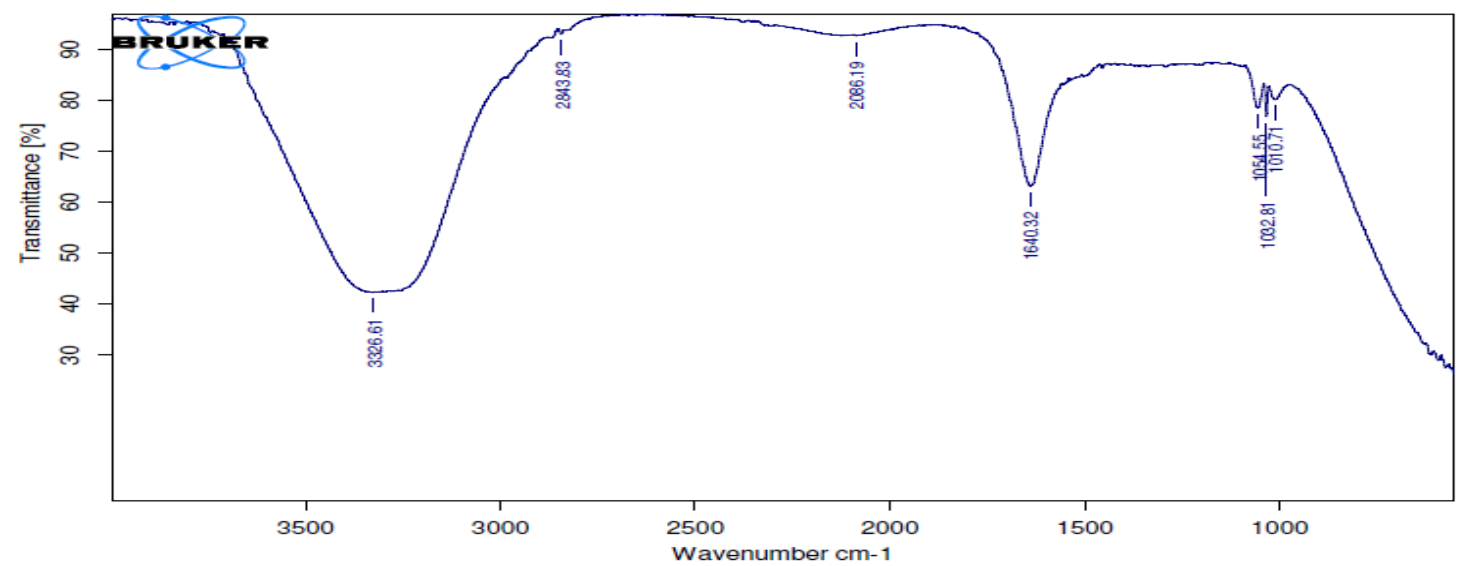

Figure 2: FTIR spectroscopy study of pure Lamivudine

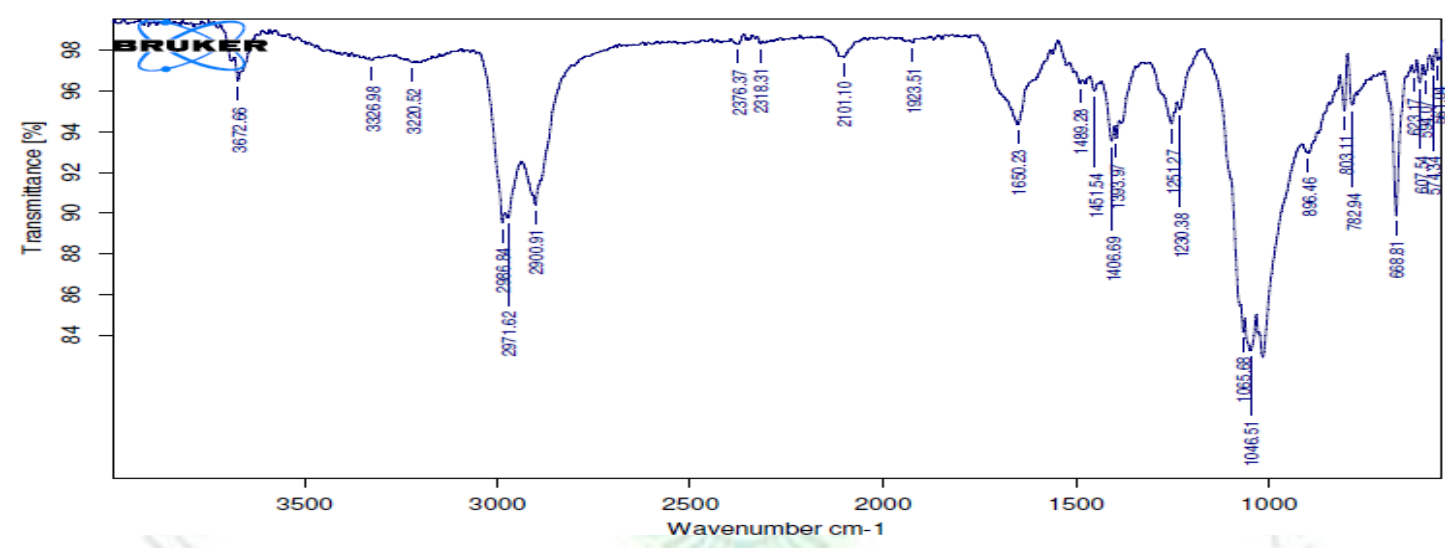

Figure 3: FTIR spectroscopy study of CF4

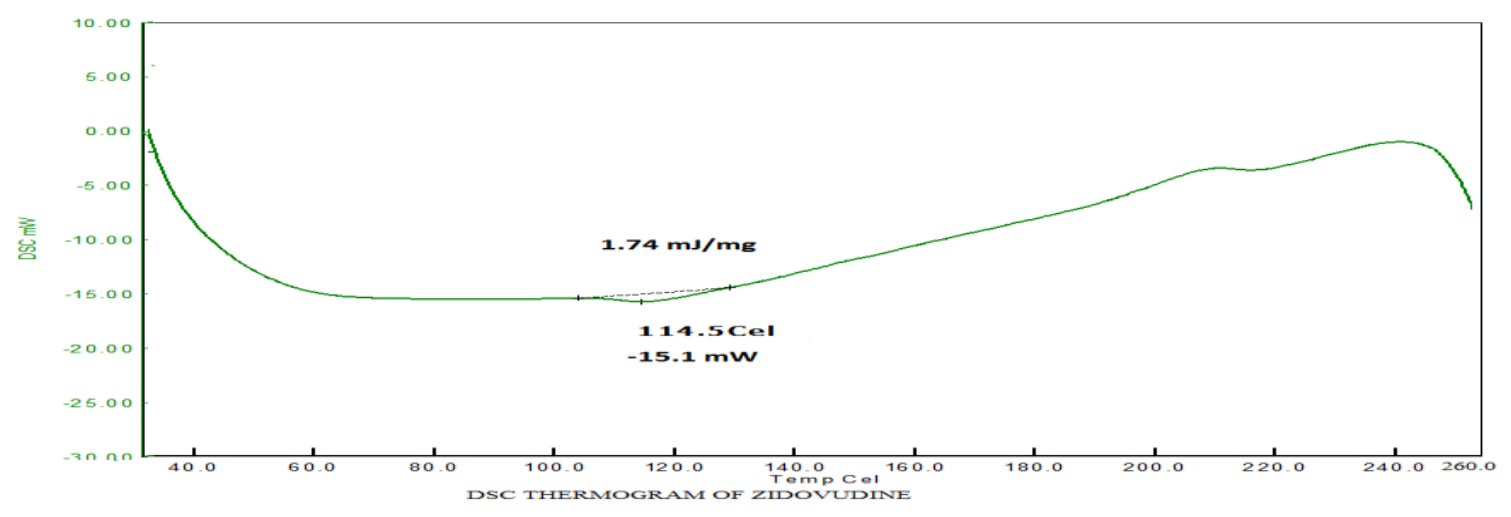

Figure 4: DSC study of Zidovudine

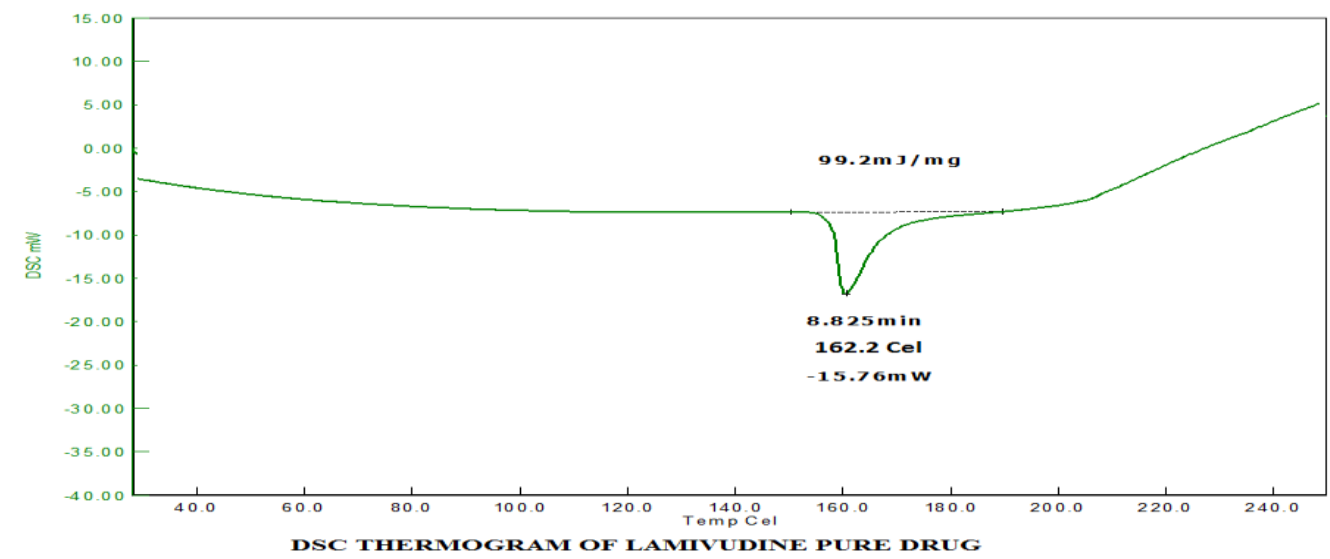

Figure 5: DSC study of Lamivudine 


\section{DSC Study}

Figure 4 indicates that the endothermic peak of Zidovudine is at $114.5^{\circ} \mathrm{C}$. The endothermic peak of Lamivudine is showing at $162.2^{\circ} \mathrm{C}$ (Figure 5).The endothermic peak of $\mathrm{CF} 4$ formulation (Figure 6) is showing at $117.6^{\circ} \mathrm{C}$ for Zidovudine and $171.2^{\circ} \mathrm{C}$ for Lamivudine. There were no significant changes in the endotherm peak between drug and formulation.

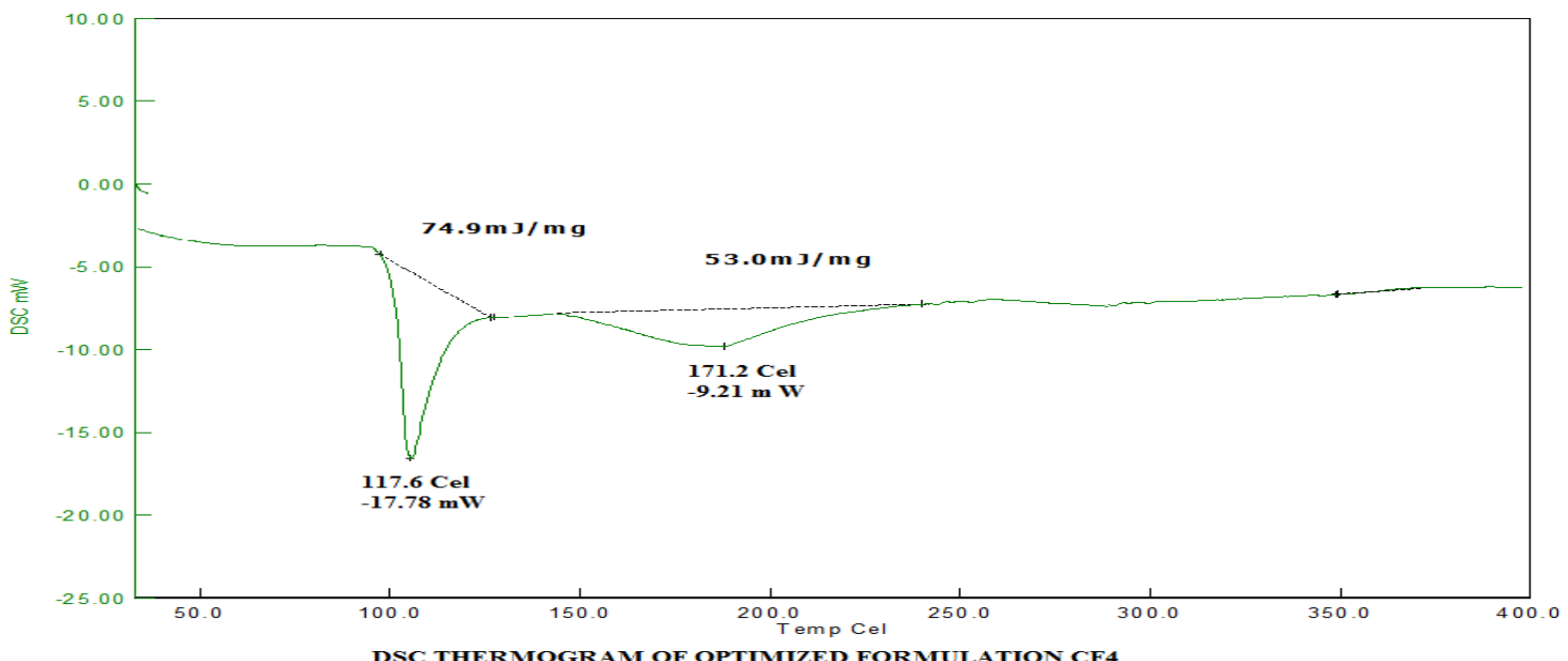

Figure 6: DSC study of CF4

\section{Pre compression parameters:}

All the compressible excipients for various batches were evaluated for angle of repose, bulk density, tapped density, Carr's index and Hausner's ratio. All the values were within acceptable limits. It is given in Table 3.

\section{Post compression parameters}

Tablets were evaluated for different post compression parameters such as thickness, coat thickness, hardness, $\%$ friability, drug content and diameter. All evaluated values were in acceptable limits. It is mentioned in Table 4.

Table 3: Pre compression parameters of powder blend

\begin{tabular}{|l|l|l|l|l|l|}
\hline $\begin{array}{l}\text { Formulation } \\
\text { code }\end{array}$ & $\begin{array}{l}\text { Angle of repose } \\
(\text { degree })^{\mathrm{a}} \pm \text { S.D }\end{array}$ & $\begin{array}{l}\text { Bulk density } \\
(\mathrm{g} / \mathrm{ml})^{\mathrm{a}} \pm \text { S.D }\end{array}$ & $\begin{array}{l}\text { Tapped density } \\
(\mathrm{g} / \mathrm{ml})^{\mathrm{a}} \pm \text { S.D }\end{array}$ & $\begin{array}{l}\text { Carr's Index } \\
(\%)^{\mathrm{a}} \pm \text { S.D }\end{array}$ & $\begin{array}{l}\text { Hausner's Ratio } \pm \\
\text { S.D }\end{array}$ \\
\hline CF1 & $27.39 \pm 0.12$ & $0.494 \pm 0.08$ & $0.536 \pm 0.14$ & $7.83 \pm 0.08$ & $1.08 \pm 0.14$ \\
\hline CF2 & $26.20 \pm 0.13$ & $0.492 \pm 0.06$ & $0.538 \pm 0.12$ & $8.55 \pm 0.06$ & $1.09 \pm 0.12$ \\
\hline CF3 & $25.08 \pm 0.13$ & $0.488 \pm 0.12$ & $0.524 \pm 0.11$ & $6.87 \pm 0.08$ & $1.07 \pm 0.11$ \\
\hline CF4 & $24.12 \pm 0.14$ & $0.485 \pm 0.13$ & $0.518 \pm 0.12$ & $6.37 \pm 0.06$ & $1.06 \pm 0.12$ \\
\hline
\end{tabular}

All values are expressed as mean \pm S.D, ${ }^{a} n=3$

Table 4: Post compression parameters of CPOP tablets

\begin{tabular}{|l|l|l|l|l|l|l|l|l|}
\hline $\begin{array}{l}\text { Formulation } \\
\text { code }\end{array}$ & $\begin{array}{l}\text { Thickness } \\
(\mathrm{mm})^{\mathrm{a}} \pm \\
\text { S.D }\end{array}$ & $\begin{array}{l}\text { Coat } \\
\text { thickness } \\
(\mu \mathrm{m})^{\mathrm{a}} \pm \\
\text { S.D }\end{array}$ & $\begin{array}{l}\text { Hardness } \\
\left(\mathrm{kg} / \mathrm{cm}^{2}\right)^{\mathrm{a}} \\
\pm \text { S.D }\end{array}$ & $\begin{array}{l}\text { \%Friability } \\
(\%)^{\mathrm{a}} \pm \text { S.D }\end{array}$ & $\begin{array}{l}\% \text { Weight } \\
\text { variation } \\
(\%)^{\mathrm{b}}\end{array}$ & $\begin{array}{l}\% \text { Drug } \\
\text { content } \\
(\%)^{\mathrm{a}} \\
\pm \text { S.D(ZD) }\end{array}$ & $\begin{array}{l}\text { \%Drug } \\
\text { content } \\
(\%)^{\mathrm{a}} \\
\pm \text { S.D } \\
(\mathrm{LM})\end{array}$ & $\begin{array}{l}\text { Diameter } \\
(\mathrm{mm})^{\mathrm{a}} \pm \\
\text { S.D }\end{array}$ \\
\hline CF1 & $4.02 \pm 0.12$ & $251.3 \pm 3.1$ & $6.9 \pm 0.12$ & $0.15 \pm 0.04$ & $1.59 \pm 0.22$ & $99.16 \pm 0.83$ & $99.02 \pm 0.83$ & $10.11 \pm 0.04$ \\
\hline CF2 & $4.05 \pm 0.14$ & $200.7 \pm 2.9$ & $6.7 \pm 0.13$ & $0.17 \pm 0.05$ & $1.45 \pm 0.21$ & $98.88 \pm 0.64$ & $98.05 \pm 0.64$ & $10.61 \pm 0.06$ \\
\hline CF3 & $4.03 \pm 0.12$ & $150.6 \pm 3.3$ & $7.3 \pm 0.12$ & $0.18 \pm 0.06$ & $1.28 \pm 0.13$ & $99.44 \pm 0.52$ & $99.11 \pm 0.52$ & $10.15 \pm 0.04$ \\
\hline CF4 & $4.02 \pm 0.03$ & $100.6 \pm 3.1$ & $6.6 \pm 0.11$ & $0.13 \pm 0.09$ & $1.12 \pm 0.25$ & $100.0 \pm 0.59$ & $99.47 \pm 0.59$ & $10.03 \pm 0.02$ \\
\hline
\end{tabular}

N.B.-All values are expressed as mean \pm S.D, ${ }^{a} n=10,{ }^{b} n=20$ 


\section{In vitro dissolution study}

The in vitro drug release characteristics were studied in $900 \mathrm{ml}$ of $0.1 \mathrm{~N} \mathrm{HCl}(\mathrm{pH} 1.2)$ for a period of first $2 \mathrm{~h}$ and 3 to $8 \mathrm{~h}$ in phosphate buffer $\mathrm{pH} 6.8$ using USP type II dissolution apparatus (Paddle type). The cumulative percentage drug release of Zidovudine for CF1, CF2, CF3 and CF4 were 82.03 $\pm 1.98,84.41 \pm 1.83$, $89.37 \pm 1.21$, and $94.14 \pm 1.22$ respectively at the end of 8 h. It is shown in figure 7 . Similarly the cumulative percentage drug release of Lamivudine for CF1, CF2, CF3 and CF4 were 85.86 $\pm 1.89,89.96 \pm 1.93$, $92.34 \pm 1.92$, and $96.89 \pm 1.02$ respectively at the end of 8 hrs. It is shown in figure 8 .

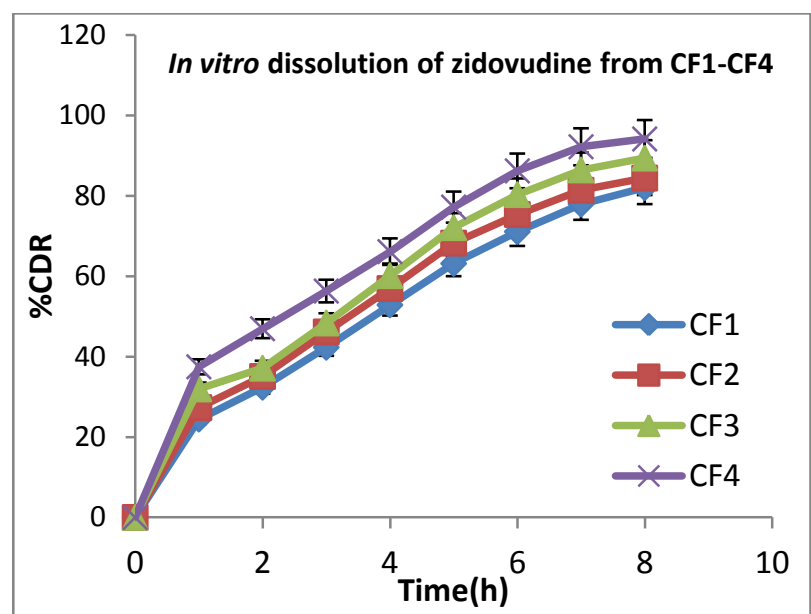

Figure 7: In vitro release profiles showing Zidovudine release from various fabricated formulations $\mathrm{CF} 1-\mathrm{CF} 4$ $(n=3)$

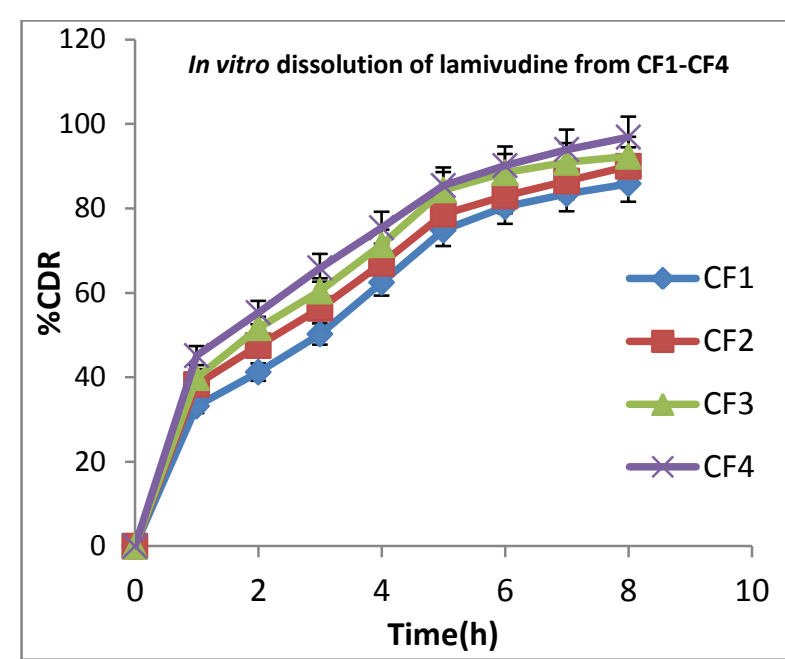

Figure 8: In vitro release profiles showing Lamivudine release from various fabricated formulations $\mathrm{CF} 1-\mathrm{CF} 4$ $(n=3)$

\section{Kinetic model}

From the kinetic it is observed that all the formulations follow non-Fickian transport mechanism for Zidovudine as the $n$ value is showing more than 0.45 in all formulations. It is shown in table 5.Similarly for Lamivudine the kinetic study was observed showing CF1 non-Fickian transport mechanism and CF2, CF3 and CF4 follow Fickian diffusion mechanism for Lamivudine. It is shown in table 6.

Table 5: Fitting of IVDR data for Zidovudine from combination in various mathematical models

\begin{tabular}{|l|l|l|l|l|l|l|l|l|l|l|l|}
\hline Models(Z) & \multicolumn{2}{l}{ Zero order } & \multicolumn{2}{l|}{ First order } & \multicolumn{2}{l|}{ Higuchi } & \multicolumn{3}{l|}{ Korsmeyer-Peppas } & \multicolumn{2}{l|}{ Hixson-Crowell } \\
\hline Batches & $\mathrm{R}^{2}$ & $\mathrm{~K}_{0}$ & $\mathrm{R}_{1}{ }^{2}$ & $\mathrm{~K}_{1}$ & $\mathrm{R}_{\mathrm{H}}{ }^{2}$ & $\mathrm{~K}_{\mathrm{H}}$ & $\mathrm{R}_{\mathrm{K}}{ }^{2}$ & $\mathrm{Kkp}$ & $\mathrm{n}$ & $\mathrm{R}^{2}$ & $\mathrm{Ks}$ \\
\hline CF1 & 0.964 & 9.779 & 0.991 & 0.209 & 0.982 & 30.09 & 0.987 & 22.75 & 0.618 & 0.995 & 0.248 \\
\hline CF2 & 0.948 & 10.04 & 0.992 & 0.232 & 0.987 & 31.22 & 0.984 & 25.46 & 0.585 & 0.992 & 0.266 \\
\hline CF3 & 0.943 & 10.51 & 0.982 & 0.278 & 0.984 & 32.75 & 0.964 & 28.64 & 0.549 & 0.989 & 0.301 \\
\hline CF4 & 0.912 & 10.66 & 0.972 & 0.347 & 0.994 & 33.94 & 0.983 & 35.31 & 0.475 & 0.987 & 0.345 \\
\hline
\end{tabular}

Table 6: Fitting of IVDR data for Lamivudine from combination in various mathematical models

\begin{tabular}{|l|l|l|l|l|l|l|l|l|l|l|l|}
\hline Models(L) & \multicolumn{2}{l}{ Zero order } & \multicolumn{2}{l|}{ First order } & \multicolumn{2}{l|}{ Higuchi } & \multicolumn{3}{l|}{ Korsmeyer-Peppas } & \multicolumn{2}{l|}{ Hixson-Crowell } \\
\hline Batches & $\mathrm{R}^{2}$ & $\mathrm{~K}_{0}$ & $\mathrm{R}_{1}{ }^{2}$ & $\mathrm{~K}_{1}$ & $\mathrm{R}_{\mathrm{H}}{ }^{2}$ & $\mathrm{~K}_{\mathrm{H}}$ & $\mathrm{R}_{\mathrm{K}}{ }^{2}$ & $\mathrm{Kkp}$ & $\mathrm{n}$ & $\mathrm{R}^{2}$ & $\mathrm{Ks}$ \\
\hline CF1 & 0.909 & 9.953 & 0.986 & 0.246 & 0.989 & 31.64 & 0.975 & 31.18 & 0.502 & 0.975 & 0.275 \\
\hline CF2 & 0.880 & 9.958 & 0.990 & 0.278 & 0.991 & 32.2 & 0.983 & 36.64 & 0.439 & 0.976 & 0.295 \\
\hline CF3 & 0.861 & 10.33 & 0.984 & 0.327 & 0.986 & 33.69 & 0.983 & 39.17 & 0.434 & 0.967 & 0.330 \\
\hline CF4 & 0.844 & 10.38 & 0.982 & 0.405 & 0.985 & 34.21 & 0.990 & 43.85 & 0.390 & 0.984 & 0.371 \\
\hline
\end{tabular}

\section{Effect of osmogen concentration}

The concentrations of fructose varied $30,60,90$, and $120 \mathrm{mg} / \mathrm{tab}$ in $\mathrm{CF} 1, \mathrm{CF} 2, \mathrm{CF} 3$, and $\mathrm{CF} 4$ respectively. The cumulative drug release was in order $\mathrm{CF} 4>\mathrm{CF} 3>\mathrm{CF} 2>\mathrm{CF} 1$ for both Zidovudine and Lamivudine respectively. It was observed that osmogent enhances the drug release of drug and thus had a direct effect on drug release. The drug release profile was shown in figure 7 for Zidovudine and figure 8 for Lamivudine.

\section{Effect of pore former concentration}

Batches CF1 to CF4 the coating composition of pore forming agent of sorbitol were $0 \%, 10 \%, 20 \%$, and $30 \%$ w/w of CA of sorbitol respectively. The cumulative drug release was in order $\mathrm{CF} 4>\mathrm{CF} 3>\mathrm{CF} 2>\mathrm{CF} 1$ for both zidovudine and lamivudine respectively. It confirms that as the level of pore former increases the membrane becomes more porous after coming contact with aqueous environment resulting in faster drug release. 
The drug release profile was shown in figure 7 for Zidovudine and figure 8 for Lamivudine.

\section{Effect of membrane thickness}

Release profiles of CPOP tablets from various batches varying the coating thickness were evaluated. The order of coating thickness for $\mathrm{CF} 1$ to $\mathrm{CF} 4$ is $\mathrm{CF} 1>\mathrm{CF} 2>\mathrm{CF} 3>\mathrm{CF} 4$. It was clearly evident that drug release was inversely proportional to coating thickness of the semi permeable membrane. The drug release profile was shown in figure 7 for Zidovudine and figure 8 for Lamivudine.

\section{Effect of flux regulating agents}

The concentrations of flux regulating agents (PEG400, PEG600, PEG4000, and PEG6000) were $33.3 \%$ w/w of $\mathrm{CA}$ in coating solution in $\mathrm{CF} 1, \mathrm{CF} 2, \mathrm{CF} 3$, and $\mathrm{CF} 4$ respectively. The cumulative drug release was in order $\mathrm{CF} 4>\mathrm{CF} 3>\mathrm{CF} 2>\mathrm{CF} 1$ for both zidovudine and lamivudine respectively. It is observed that type of flux regulating agents have pronounced effect on drug release. Hence the type of flux regulating agents on drug release is written as PEG6000> PEG4000 $>$ PEG600 $>$ PEG400. The drug release profile was shown in figure 7 for Zidovudine and figure 8 for Lamivudine.

\section{Effect of osmotic pressure on optimized formulation}

The results of release studies of optimized formulation in media of different osmotic pressure indicated that the drug release is highly dependent on the osmotic pressure of the release media. The release was inversely related to the osmotic pressure of release media. This finding confirms that the mechanism of drug release is by osmotic pressure. The drug release of Zidovudine for CF4 was found to be $90.32 \pm 1.71 \%$ for 30 atm, $86.78 \pm 1.72 \%$ for $60 \mathrm{~atm}$ and $82.43 \pm 1.74 \%$ for $90 \mathrm{~atm}$ respectively. It is shown in figure 9.Similarly the drug release of Lamivudine for $\mathrm{CF} 4$ was found to be $93.47 \pm 1.74 \%$ for $30 \mathrm{~atm}, 89.16 \pm 1.74 \%$ for $60 \mathrm{~atm}$ and $84.28 \pm 1.70 \%$ for $90 \mathrm{~atm}$ respectively. It is shown in figure 10 .

\section{Effect of pH}

The optimized formulation CF4 was subjected to in vitro drug release studies of Zidovudine and Lamivudine differently in buffers with different $\mathrm{pH}$ like $\mathrm{pH} 1.2, \mathrm{pH}$ 6.8 and $\mathrm{pH}$ 7.4. It is observed that there is no significant difference in the release profile for Lamivudine and Zidovudine from combination, demonstrating that the developed formulation shows $\mathrm{pH}$ independent release.

\section{Effect of agitation intensity}

The optimized formulation of CF4 batch was carried out in USP dissolution apparatus type-II at varying rotational speed $(50,100$ and 150rpm) for Zidovudine and Lamivudine from combination. It shows that the release of both the drugs from CPOP is independent of agitation intensity.

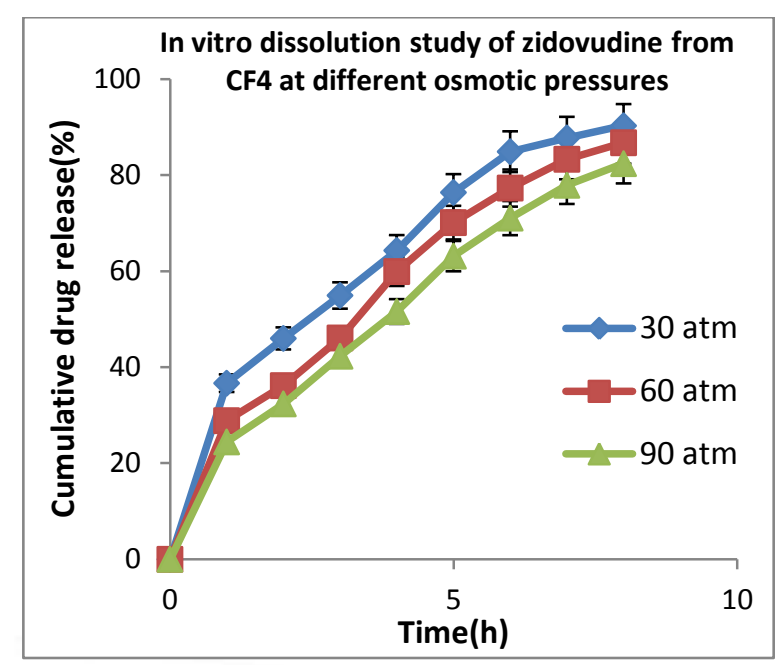

Figure 9: In vitro release profiles showing Zidovudine release from best CF4 in different osmotic pressures

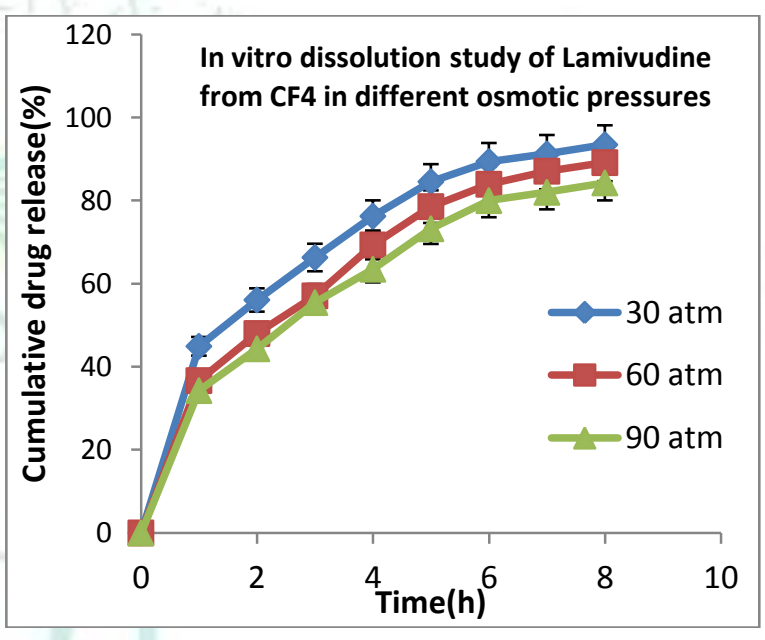

Figure 10: In vitro release profiles showing Lamivudine release from best $\mathrm{CF} 4$ in different osmotic pressures

\section{Scanning Electron Microscopy (SEM)}

The coating membrane of the osmotic delivery system before and after dissolution was examined with the help of SEM. Before dissolution (Figure11a) no pores were found in the coating membrane. But after dissolution (Figure 11b) comparatively more numbers of pores were found in the membrane might be due to leaching or removal of entrapped drug from the formulation. The porosity nature of the membrane was due to the presence of pore forming agent sorbitol in the formulation. 


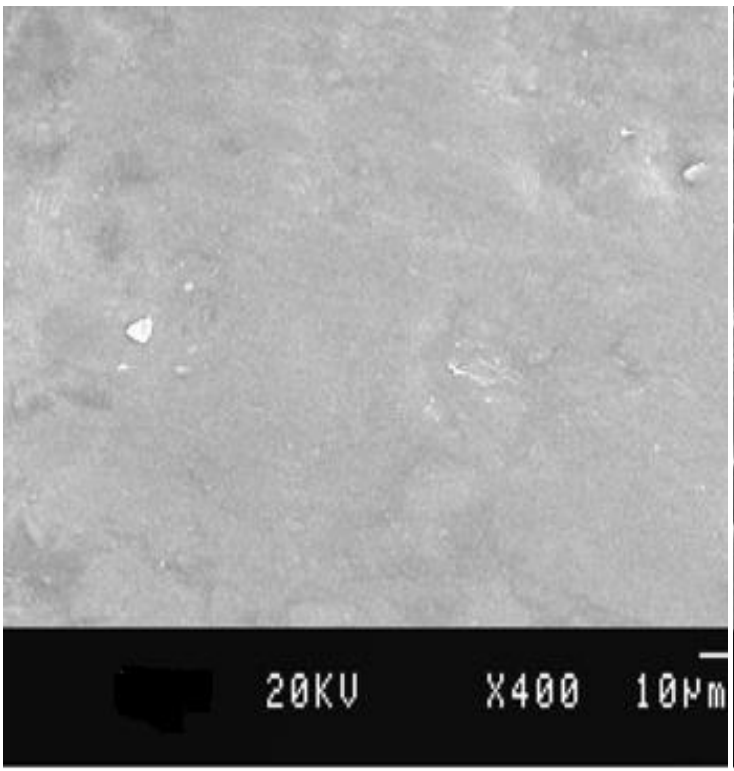

a) SEM before dissolution

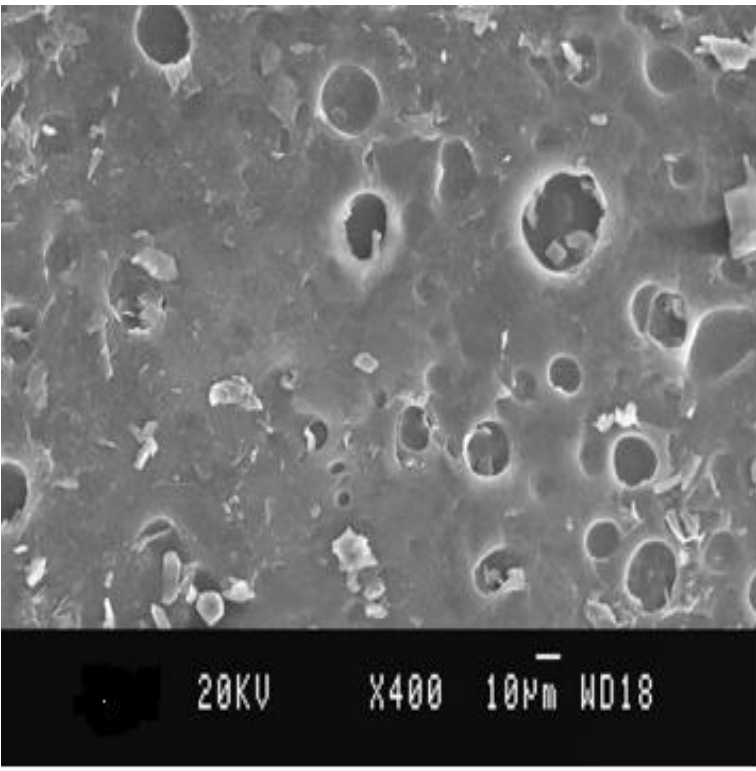

b) SEM after dissolution

Figure 11: a) SEM of membrane structure of optimized formulation before dissolution, b) SEM of membrane structure of optimized formulation after dissolution

\section{Stability studies}

From short term stability studies of optimized formulation $\mathrm{CF} 4$, it was confirmed that there was no significance changes in physical appearance and drug content. It is shown in table 7.

Table 7: Comparative physicochemical characterization of CF4 at accelerated conditions

\begin{tabular}{|c|c|c|c|c|c|}
\hline S.N. & Parameters & Initial & $\begin{array}{ll}\text { After } & 30 \\
\text { days }\end{array}$ & $\begin{array}{ll}\text { After } \\
\text { days }\end{array}$ & $\begin{array}{ll}\begin{array}{l}\text { After } \\
\text { days }\end{array} & 90 \\
\end{array}$ \\
\hline 1. & Physical appearance & $\begin{array}{l}\text { Pale white, circular, concave } \\
\text { smooth surface without any } \\
\text { cracks }\end{array}$ & No change & No change & No change \\
\hline 2. & Thickness $(\mathrm{mm})^{\mathrm{a}} \pm$ S.D & $4.02 \pm 0.03$ & $4.02 \pm 0.03$ & $4.01 \pm 0.02$ & $4.01 \pm 0.05$ \\
\hline 3 & $\operatorname{Hardness}\left(\mathrm{kg} / \mathrm{cm}^{2}\right)^{\mathrm{a}} \pm$ S.D & $6.6 \pm 0.11$ & $6.6 \pm 0.11$ & $6.5 \pm 0.14$ & $6.5 \pm 0.12$ \\
\hline 4. & Friability $(\%)^{\mathrm{a}} \pm$ S.D & $0.13 \pm 0.09$ & $0.13 \pm 0.09$ & $0.14 \pm 0.08$ & $0.14 \pm 0.06$ \\
\hline 5 & Weight variation $(\mathrm{mg})^{\mathrm{b}} \pm$ S.D & $1.12 \pm 0.25$ & $1.12 \pm 0.25$ & $1.13 \pm 0.29$ & $1.15 \pm 0.25$ \\
\hline 6. & Drug content $(\%)^{\mathrm{a}} \pm \mathrm{S} . \mathrm{D}(\mathrm{ZD})$ & $100.0 \pm 0.59$ & $100.0 \pm 0.59$ & $99.2 \pm 0.52$ & $99.17 \pm 0.56$ \\
\hline 7. & Drug content $(\%)^{\mathrm{a}} \pm$ S.D $(\mathrm{LM})$ & $99.47 \pm 0.59$ & $99.47 \pm 0.59$ & $99.11 \pm 0.25$ & $99.08 \pm 0.32$ \\
\hline
\end{tabular}

N.B.-All values are expressed as mean \pm S.D, ${ }^{a} n=10,{ }^{b} n=20$

\section{CONCLUSION}

The drug release from CPOP was in predetermined rate and predetermined time by incorporating controlled release polymer and osmogen. It was confirmed that increase in concentration of osmogen the drug release from the system was found to be increased.SEM study reveals that the mechanism of drug releases due to osmogen as well as pore former. Hence this can be used to develop newer formulations to avoid shortcomings of conventional dosage forms.

\section{Acknowledgements}

The authors would like to acknowledge the contributions of Pharmaceutics Department, Faculty of Pharmacy, University College of Technology, Osmania University, Hyderabad, Telangana, India for providing necessary facilities to carry out the research work. This study was part of a PhD thesis under Osmania University, Hyderabad. 


\section{REFERENCES}

1. Chein YW. Novel Drug Delivery Systems ed by Chein YW, Marcel Dekker, Inc., New York, USA 1992; 139-196.

2. Sahoo CK, Rao SRM, Sudhakar M and Sahoo NK. Advances in osmotic drug delivery system. J of Chemical and Pharmaceutical Research. 2015; 7:252-273.

3. Zenter GM, Rork GS, Himmelstein KJ. The controlled porosity osmotic pump. J control release; 1985; 1:269-282.

4. Verma RK, Krishna DM, Garg S. Formulation aspects in the development of osmotically controlled oral drug delivery systems. J control release; 2000; 79:7-27.

5. Sahoo CK, Sahoo NK, Rao SRM, Sudhakar M. A Review on Prevention and Treatment of Aids. Pharm Pharmacol Int J. 2017; 5(1):00108.

6. Michael J. Mugavero, Charles B. Hicks, HIV resistance and the effectiveness of combination antiretroviral treatment Drug Discovery Today: Therapeutic strategies 2004; 1(4):529-535.

7. Jilakara VS, Chowdary YA. Formulation and evaluation of sustained release matrix tablets of Zidovudine, Int. J. Pharm. Sci. Rev. Res. 2013; 18(1):143-149.

8. Kumaravelrajan R, Narayanan N, Suba V. Development and evaluation of controlled porosity osmotic pump for Nifedipine and Metoprolol combination. Lipids in Health and Disease.2011; 10:51

9. Sahoo CK, Sahoo NK, Rao SRM, Sudhakar M, Satyanarayana K. A review on controlled porosity osmotic pump tablets and its evaluation. Bulletin of Faculty of Pharmacy, Cairo University, 2015; 53(2):195-205.

10. Sahoo CK, Rao SRM, Sudhakar M. Evaluation of controlled porosity osmotic pump tablets a review. Research J. Pharm. And Tech. 2015; 8(12):119-125.

11. Sirisha VNL, Rao YKK, Eswaraiah MC. Formulation and evaluation of Lamivudine and Zidovudine extended release tablets, Int. J. of Research in Pharmaceutical and Biomedical Sciences.2012;3(4):1759-1763.
12. Costa P, Lobo JMS. Modelling and comparison of dissolution profiles, European J of Pharmaceutical Sciences, 2001; 13:123-133.

13. Sahoo CK, Rao SRM, Sudhakar M and Kokkula S. The kinetic modeling of drug dissolution for drug delivery systems: an overview. Der Pharmacia Lettre 2015; 7(9):186194.

14. Sharma F, Jain H, Kanzariya V, Upadhyay U. Formulation and evaluation of controlled release osmotic tablet of metoprolol succinate. Asian J. Pharm Clin Res 2014; 7(3):3843.

15. Banerjee A, Verma PRP, Gore S. Controlled porosity solubility modulated osmotic pump tablets of Gliclazide.AAPS Pharm Sci Tech 2015; 16(3):554-568.

16. Kuksal A, Tiwary AK, Jain NK, Jain S. Formulation and in vitro, in vivo evaluation of extended release matrix tablet of Zidovudine: influence combination of hydrophilic and hydrophobic matrix formers. AAPS Pharm Sci Tech 2006; 7(1):E1-E9.

17. Khan ZA, Tripathi R, Misha B. Design and evaluation of enteric coated microporous osmotic pump tablet (ECMOPT) of quetiapine fumarate for the treatment of psychosis. Acta Poloniae -Drug Research 2012; 69(6):1125-1136.

18. Kanagale P, Lohay BB, Misra A, Davadra P, Kini R. Formulation and Optimization of Porous Osmotic Pump based Controlled Release System of Oxybutynin.AAPS Pharm SciTech. 2007; 8(3):E1-E7. Pore former

19. Rao BP, Geetha M, Purushothama N, Sanki U. Optimization and development of swellable controlled porosity osmotic pump tablet for theophylline. Trop. J. Pharm Res.2009; 8(3):247-255.

20. Cartensen JT. Drug stability: Principle and practices, Marcel Dakker, New York, $2^{\text {nd }}$ ed. $1995 ; 538-550$. 